Article

\title{
Environmentally Relevant Concentrations of Triclosan Induce Cyto-Genotoxicity and Biochemical Alterations in the Hatchlings of Labeo rohita
}

\author{
Sunil Sharma ${ }^{1}$, Owias Iqbal Dar ${ }^{1}\left[\right.$, , Megha Andotra ${ }^{1}$, Simran Sharma ${ }^{1}$, Arvinder Kaur ${ }^{1, *}$ \\ and Caterina Faggio $2, *$ (D) \\ 1 Aquatic Toxicology Lab, Department of Zoology, Guru Nanak Dev University, Amritsar 143005, Punjab, India \\ sunilkerni87@gmail.com (S.S.); owiaszolo@gmail.com (O.I.D.); andotramegha@gmail.com (M.A.); \\ simransharma6696@gmail.com (S.S.) \\ 2 Department of Chemical, Biological, Pharmaceutical and Environmental Sciences University of Messina, \\ 98166 Messina, Italy \\ * Correspondence: arvinder165@gmail.com (A.K.); cfaggio@unime.it (C.F.)
}

check for updates

Citation: Sharma, S.; Iqbal Dar, O.; Andotra, M.; Sharma, S.; Kaur, A.;

Faggio, C. Environmentally Relevant Concentrations of Triclosan Induce Cyto-Genotoxicity and Biochemical Alterations in the Hatchlings of Labeo rohita. Appl. Sci. 2021, 11, 10478. https://doi.org/10.3390/ app112110478

Academic Editors: Ramaraj Boopathy and Ibrahim M. Banat

Received: 1 October 2021

Accepted: 5 November 2021

Published: 8 November 2021

Publisher's Note: MDPI stays neutral with regard to jurisdictional claims in published maps and institutional affiliations.

Copyright: (c) 2021 by the authors. Licensee MDPI, Basel, Switzerland. This article is an open access article distributed under the terms and conditions of the Creative Commons Attribution (CC BY) license (https:/ / creativecommons.org/licenses/by/ $4.0 /)$.

\begin{abstract}
Xenobiotic Triclosan (TCS) is of great concern because of its existence in a variety of personal, household and healthcare products and continuous discharge in water worldwide. Excessive use of TCS-containing sanitizers and antiseptic products during the COVID-19 pandemic further increased its content in aquatic ecosystems. The present study deals with the cyto-genotoxic effects and biochemical alterations in the hatchlings of Labeo rohita on exposure to environmentally relevant concentrations of TCS. Three-days-old hatchlings were exposed to tap water, acetone (solvent control) and 4 environmentally relevant concentrations $(6.3,12.6,25.2$ and $60 \mu \mathrm{g} / \mathrm{L})$ of TCS for 14 days and kept for a recovery period of 10 days. The significant concentration-dependent decline in cell viability but increase in micronucleated cells, nucleo-cellular abnormalities (NCAs) and DNA damage parameters like tail length, tail moment, olive tail moment and percent of tail DNA after exposure persisted till the end of recovery period. Glucose, triglycerides, cholesterol, total protein, albumin, total bilirubin, uric acid and urea (except for an increase at $60 \mu \mathrm{g} / \mathrm{L}$ ) showed significant $(p \leq 0.05)$ concentration-dependent decrease after 14 days of exposure. The same trend (except for triglycerides, albumin and total bilirubin) continued till 10 days post exposure. In comparison to control, transaminases (alanine and aspartate aminotransferases) increased $(p \leq 0.05)$ after exposure as well as the recovery period, while a decline in alkaline phosphatase after exposure was followed by a significant increase during the recovery period. The results show that the environmentally relevant concentrations of TCS cause deleterious effects on the hatchlings of L. rohita.
\end{abstract}

Keywords: triclosan; environmentally relevant concentrations; L. rohita; hatchlings; cytotoxicity; genotoxicity; biochemical alterations

\section{Introduction}

Excessive use of pharmaceuticals and personal care products (PPCPs) by the modern population has loaded the aquatic ecosystems with xenobiotics [1]. PPCPs are a class of emerging contaminants ubiquitously found in water and soil all over the world and cause deleterious effects on humans and non-target organisms. Triclosan (TCS), a common antibacterial and antifungal agent, is incorporated in a majority of household products such as soap, shampoo, detergent, cleansing kits, chopping boards and containers. During the COVID-19 pandemic, excessive use of TCS-containing sanitizers and handwash has further increased its discharge into water bodies. One of the serious issues related to TCS is its incomplete removal by the conventional waste water treatment plants [2]. Dhillon et al. [3] reported concentrations of TCS in the range of $0.0014-40 \mu \mathrm{g} / \mathrm{L}$ in the surface water of lakes, rivers and streams with direct input of raw waste water and in the range of 
$100-53,000 \mu \mathrm{g} / \mathrm{kg}$ dry weight in the sediments of fresh water bodies. The concentration of TCS has been reported to be 3.8-5.16 $\mu \mathrm{g} / \mathrm{L}$ in the Tamiraparani River of India [4]. However, Nag et al. [5] detected TCS levels in the range of $1.1-9.65 \mu \mathrm{g} / \mathrm{L}$ in the surface water, $5.11-50.36 \mu \mathrm{g} / \mathrm{kg}$ in the sediments and $13-1040 \mu \mathrm{g} / \mathrm{kg}$ in the fish of the Gomti River in India. High concentrations of TCS have also been recorded in different fish species $(91.1-589 \mu \mathrm{g} / \mathrm{kg}$ ) of the Torsa River in India [6].

TCS is reported to cause varying degrees of toxicity in aquatic organisms such as developmental abnormalities [7], behavioral alterations [8], hematological and histopathological changes [9], endocrine disruption [10], oxidative stress [7,11] and transcriptomic alterations [12,13]. Due to its antiseptic nature, it disturbs normal cell functions, which leads to cytotoxic [14], clastogenic and aneugenic effects in organisms. Earlier studies have reported significant cytotoxic and genotoxic effects from TCS in Dreissena polymorpha [15], Oreochromis niloticus [16], embryos of Danio rerio [17], Pangasianodon hypophthalmus [18,19], adult zebra fish [20] and Labeo rohita $[9,13]$.

Of all the organisms, fishes are sensitive to even low levels of such xenobiotics in a water body, as these may enter the fish body from water as well as food at the same time and affect its normal physiology, biochemistry and metabolism [21-24]. Biochemical profiling in fishes is consideredas an essential tool against environmental stress, as it provides an early warning signal for the target organs of toxicity and health status of fish and aquatic ecosystem [25]. TCS-induced significant biochemical changes have been reported in zebra fish [26], Channa punctatus [27], Oreochromis niloticus [16], Labeo rohita [9] and Catla catla [28]. Marked variations in biochemical parameters may ultimately cause harmful effects in both exposed fishes and consumers.

The goal of the present study was to evaluate the cyto-genotoxicity and biochemical toxicity of 4 environmentally relevant concentrations $(6.3,12.6,25.2$ and $60 \mu \mathrm{g} / \mathrm{L})$ of TCS to the hatchlings of an important food fish, L. rohita, after 14 days of exposure and 10-days depuration period. The selected concentrations were $1 / 20,1 / 10,1 / 5$ and $1 / 2$ of 96-h $\mathrm{LC}_{50}$ of TCS for the hatchlings already reported in our previous study [13], and the interaction of fish with these levels of TCS is expected in nature. The selected concentrations were non-lethal, and evaluation of the biochemical and genotoxicity parameters after extended exposure to these concentrations had its own importance because of the absence of immediate visible signs of toxicity. Physiological similarity of fish with mammals, higher sensitivity and susceptibility in their early stages to stress $[11,29,30]$ and importance of fish in the food chain of man make the results suitable for setting safety limits for food fish. To the best of our knowledge, no study has reported the effect of sublethal concentrations of TCS on the selected parameters in the early life stages of fish till date.

\section{Materials and Methods}

\subsection{Chemicals}

TCS, with the commercial name Irgasan (CAS 3380-34-5 and purity $\geq 97 \%$ ), was purchased from Sigma-Aldrich (Burlington, MA, USA), and a stock solution of $10 \mathrm{mg} / \mathrm{mL}$ was prepared in acetone. All other chemicals used in the study were of analytical grade.

\subsection{Test Organisms}

Fertilized eggs of L. rohita were collected from the circular hatchery of the government fish seed farm, Rajasansi, Amritsar. The embryos were transported in oxygenated bags to laboratory and kept for hatching in plastic pools (10-L capacity) containing dechlorinated tap water ( $\mathrm{pH} 7.3-7.9$ and temperature $25 \pm 1.2{ }^{\circ} \mathrm{C}$ ). Three-days-old hatchlings (total: 1200; 200 /concentration with 5 replicates containing 40 hatchlings each) were exposed to tap water (control), acetone (vehicle control) 6.3, 12.6, 25.2 and $60 \mu \mathrm{g} / \mathrm{L}$ TCS for 14 days. The highest concentration $(60 \mu \mathrm{g} / \mathrm{L})$ was $\mathrm{LC}_{0}$ in our previous study [13]. The test water was changed on alternate days after $1 \mathrm{~h}$ of feeding the hatchlings with boiled egg yolk. After 14 days, pooled hatchlings from each replicate were used for cyto-genotoxicity [cell viability (10), comet (20) and micronucleus assays (20)] and biochemical studies (50), and the 
remainingr were kept for 10 days in tap water to recover from the stress of TCS exposure. The same tests were performed after recovery, and the number of hatchlings used for the cell viability, comet, $\mathrm{MN}$ and biochemical studies were $6,12,12$ and 30, respectively. Average weight of the hatchlings after exposure and the recovery period were 2.0 and $3.4 \mathrm{mg}$, respectively.

\subsection{Cell Viability Test}

Hatchlings were homogenized in $500 \mu \mathrm{L}$ of phosphate buffer saline ( $\mathrm{pH} 7.4)$ and centrifuged at $500 \times g$ for $10 \mathrm{~min}$. Supernatant was discarded, and the pellet was resuspended in $500 \mu \mathrm{L}$ PBS and centrifuged again. After 3-4 consecutive centrifugations, the pellet was resuspended in $100 \mu \mathrm{L}$ PBS. Then, $5 \mu \mathrm{L}$ of cell suspension and $24 \mu \mathrm{L}$ of dye $(100 \mu \mathrm{g} / \mathrm{mL}$ ethidium bromide and $100 \mu \mathrm{g} / \mathrm{mL}$ acridine orange) were taken on a slide, covered with a coverslip, scanned under a Nikon ECLIPSE E200 (Tokyo, Japan) fluorescent microscope at $40 \times$ and photographed with Nikon D5300 camera. The viable cells appeared green, the necrotic cells were red, and the apoptotic cells were yellow (Figure 1) as suggested by Er et al. [31]. A total of 1500 cells/exposure group (500/replicate) were scored for this study.
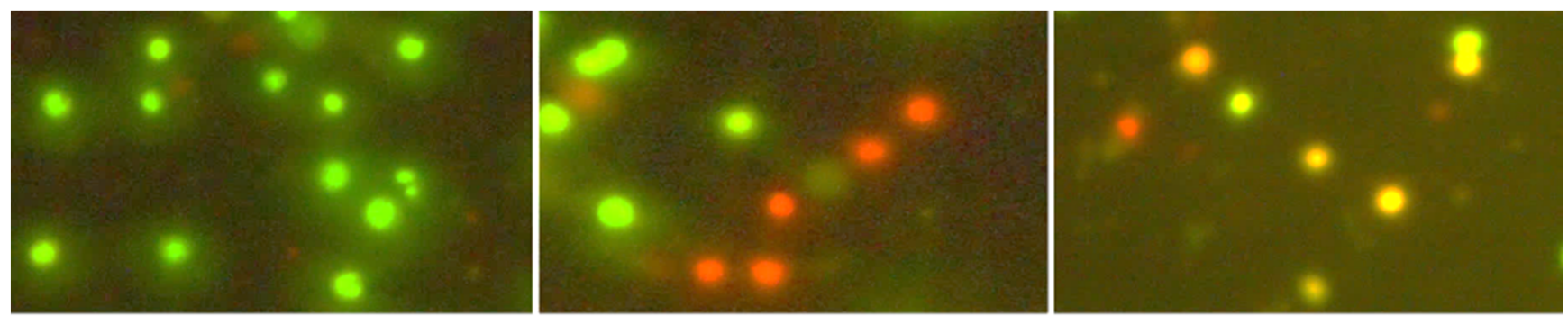

Figure 1. Photographs showing viable cells (green), necrotic cells (red) and apoptotic cells (yellow).

\subsection{Micronucleus Assay}

Micronucleus assay was performed by the protocol of Sharma and Chadha [32] with some modifications. Hatchlings were kept in $1 \mathrm{~mL}$ Carnoy's fixative (6:3:1 ethanol:chloroform: acetic acid) for $1 \mathrm{~h}$. The hatchlings were then kept in $25 \%$ acetic acid for $15 \mathrm{~min}$, homogenized and centrifuged at $500 \times g$ for $10 \mathrm{~min}$. Supernatant was discarded, and centrifugation was repeated 2-3 times after the addition of fresh $25 \%$ acetic acid. Finally, the pellet was resuspended in $100 \mu \mathrm{L}$ of acetic acid and smeared on a clean slide. The slide was dried at room temperature and stained with $5 \%$ Giemsa for $30 \mathrm{~min}$. The slides were destained with distilled water, dried properly and scanned under an Olympus BX43 microscope at $100 \times$ magnification. A total of 1500 cells/treatment (500 per replicate) were scored for the presence of micronuclei (MN) and nucleo-cellular abnormalities (NCAs).

\subsection{Comet Assay}

Comet assay was performed according to the method of Singh et al. [33] with slight modifications. Cell suspension was prepared by homogenizing approximately $40 \mathrm{mg}$ of hatchlings in $1 \mathrm{~mL}$ of PBS (pH 7.4). The glass slides were coated with $1 \%$ normal melting point agarose $12 \mathrm{~h}$ prior to second layer. The second layer of $35 \mu \mathrm{L}$ of the cell suspension mixed with $120 \mu \mathrm{L}$ of $0.5 \%$ low melting point agarose (LMPA) was applied over the base layer and covered with a coverslip. Slides were again coated with $150 \mu \mathrm{L}$ of $0.5 \%$ LMPA. After complete gel solidification, slides were immersed in lysis buffer $(\mathrm{pH} 10)$ for $3 \mathrm{~h}$ at $4{ }^{\circ} \mathrm{C}$ in dark. Then, the slides were subjected to electrophoresis for $20 \mathrm{~min}$ in electrophoresis buffer at $300 \mathrm{~mA}$ and $20 \mathrm{~V}$. Finally, the slides were neutralized with Tris buffer ( $\mathrm{pH}$ 7.4) for $15 \mathrm{~min}$ and stained with ethidium bromide. A total of 300 cells per exposure group (100 per replicate) were scanned under a fluorescent microscope (Nikon ECLIPSE E200) at $40 \times$ and photographed with a Nikon D5300 camera. Casp Lab software was used to 
evaluate the extent of DNA damage in the form of tail length (TL), tail moment (TM), olive tail moment (OTM) and percent tail DNA (\%TDNA).

\subsection{Biochemical Changes}

The hatchlings $(100 \mathrm{mg}$ ) were homogenized in $1 \mathrm{~mL}$ of PBS (7.4) and centrifuged at 10,000 rpm for $25 \mathrm{~min}$. The levels of glucose (Glu), triglycerides (TG), cholesterol (Chol), total protein (TP), albumin (Alb), urea (U), uric acid (UA), total bilirubin (Tbili), alkaline phosphatase (ALP), aspartate transaminase (AST) and alanine transaminase (ALT) were estimated by a Benesphera Clinical Chemistry C71 analyzer, Pennsylvania, United States (using Ebra Mannheim kits).

\subsection{Statistical Analysis}

One-way ANOVA was used to find out significance level ( $p \leq 0.05$ and $p \leq 0.01)$ between treatments, and $t$-test was used for comparing the exposure and recovery values. Tukey's HSD test was performed to obtain differences among the means. The results have been presented as mean \pm SD. Statistical analysis was carried out with the help of SPSS version 16.0.

\section{Results}

\subsection{Cytotoxicity}

There was a significant $(p \leq 0.01)$ concentration-dependent reduction in the frequency of viable cells after exposure as well as the recovery period (Table 1). The decline at 6.3, $12.6,25.2$ and $60 \mu \mathrm{g} / \mathrm{L}$ was $4.9,6.3,14.43$ and $17.82 \%$ after exposure and $1.42,6.96,8.69$ and $12.65 \%$ after the recovery period, respectively. The necrotic and apoptotic cell frequencies, on the other hand, increased significantly $(p \leq 0.01)$ in a concentration-dependent manner after exposure and recovery. After 14 days of exposure, the increase at 6.3, 12.6, 25.2 and $60 \mu \mathrm{g} / \mathrm{L}$ was $34.28,45.71,116.14$ and $151.43 \%$ for the necrotic cells and 83.40, 102.43, 199.59 and $223.89 \%$ for the apoptotic cells, respectively. Percent increase over control after recovery was $9.61,28.09,47.45$ and $91.12 \%$ for necrotic cells and $14.74,104.67,109.58$ and $122.85 \%$ for the apoptotic cells at 6.3, 12.6, 25.2 and $60 \mu \mathrm{g} / \mathrm{L}$, respectively. After recovery, percentage of viable and apoptotic cells increased significantly $(p \leq 0.01)$ over exposure values only at 60 and $12.6 \mu \mathrm{g} / \mathrm{L}$, respectively, while that of necrotic cells declined significantly only at the highest concentration.

Table 1. TCS-induced variation in viable, necrotic and apoptotic cells during the exposure and recovery period.

\begin{tabular}{ccccc}
\hline Treatment & & Viable Cells (\%) & Necrotic Cells (\%) & Apoptotic Cells (\%) \\
\hline \multirow{2}{*}{ Control } & $\mathrm{E}$ & $90.53 \pm 0.11^{\mathrm{d}}$ & $7.00 \pm 0.53^{\mathrm{a}}$ & $2.47 \pm 0.42^{\mathrm{a}}$ \\
& $\mathrm{R}$ & $89.07 \pm 0.64^{\mathrm{r}}$ & $6.87 \pm 0.42^{\mathrm{p}}$ & $4.07 \pm 0.23^{\mathrm{p}}$ \\
\hline \multirow{2}{*}{ Acetone } & $\mathrm{E}$ & $90.67 \pm 0.90^{\mathrm{d}}$ & $7.13 \pm 0.50^{\mathrm{a}}$ & $2.20 \pm 0.40^{\mathrm{a}}$ \\
& $\mathrm{R}$ & $89.00 \pm 0.40^{\mathrm{r}}$ & $7.07 \pm 0.30^{\mathrm{p}}$ & $3.93 \pm 0.42^{\mathrm{p}}$ \\
\hline \multirow{2}{*}{$6.3 \mu \mathrm{g} / \mathrm{L}$} & $\mathrm{E}$ & $86.07 \pm 1.51^{\mathrm{c}}$ & $9.40 \pm 1.11^{\mathrm{ab}}$ & $4.53 \pm 0.50^{\mathrm{b}}$ \\
& $\mathrm{R}$ & $87.80 \pm 0.35^{\mathrm{r}}$ & $7.53 \pm 0.50^{\mathrm{pq}}$ & $4.67 \pm 0.30^{\mathrm{p}}$ \\
\hline \multirow{2}{*}{$12.6 \mu \mathrm{g} / \mathrm{L}$} & $\mathrm{E}$ & $84.80 \pm 0.60^{\mathrm{c}}$ & $10.20 \pm 0.40^{\mathrm{b}}$ & $5.00 \pm 0.53^{\mathrm{b}}$ \\
& $\mathrm{R}$ & $82.87 \pm 1.94^{\mathrm{q}}$ & $8.80 \pm 1.44^{\mathrm{pq}}$ & $8.33 \pm 0.50^{\mathrm{q}}$ \\
\hline \multirow{2}{*}{$25.2 \mu \mathrm{g} / \mathrm{L}$} & $\mathrm{E}$ & $77.47 \pm 1.92^{\mathrm{b}}$ & $15.13 \pm 1.40^{\mathrm{c}}$ & $7.40 \pm 0.53^{\mathrm{c}}$ \\
& $\mathrm{R}$ & $81.33 \pm 2.05^{\mathrm{q}}$ & $10.13 \pm 1.55^{\mathrm{q}}$ & $8.53 \pm 0.50^{\mathrm{q}}$ \\
\hline \multirow{2}{*}{$60 \mu \mathrm{g} / \mathrm{L}$} & $\mathrm{E}$ & $74.40 \pm 1.83^{\mathrm{a}}$ & $17.60 \pm 1.44^{\mathrm{d}}$ & $8.00 \pm 0.40^{\mathrm{c}}$ \\
& $\mathrm{R}$ & $77.80 \pm 1.05^{\mathrm{p}}$ & $13.13 \pm 1.33^{\mathrm{r}}$ & $9.07 \pm 0.30^{\mathrm{q}}$ \\
\hline Exposure & $\mathrm{F}$ & $78.77^{* *}$ & $57.49^{* *}$ & $74.47^{* *}$ \\
\hline Recovery & $\mathrm{F}$ & $40.21^{* *}$ & $15.25^{* *}$ & $117.10^{* *}$ \\
\hline
\end{tabular}

Values are mean $\pm \mathrm{SD}, \mathrm{n}=3$, and different alphabets represent significant $(p \leq 0.01)$ differences within the treatments after exposure $(\mathrm{E})(\mathrm{a}-\mathrm{d})$ and recovery $(\mathrm{R})(\mathrm{p}-\mathrm{r}) .{ }^{* *}$ represents $1 \%$ significance level. 


\subsection{Micronucleus Assay}

Frequency of MN and NCA increased significantly $(p \leq 0.01)$ in a concentrationdependent manner after the exposure and recovery period. After depuration, the frequency of NCA was also significantly $(p \leq 0.01)$ higher than the respective exposure values (Table 2). After 14 days of exposure, only micronuclei, binucleated cells and nuclear fragmentation were observed, but after recovery, along with these, blebbed nuclei, notched nuclei, nuclear buds, deformed nuclei, vesicle formation, extrusion of nuclei, ghost cells, stickiness, cytoplasmic bridges, vacuolation and lytic or necrotic cells were prominent (Figure 2). The maximum increase over control was observed in the frequency of cells with nuclear fragmentation (4.39-fold) and binucleated cells (2.05-fold) after 10 days of recovery at the highest concentration. The increase over control in MN and NCA frequencies at the highest concentration was 5.45- and 3.46-fold, respectively, after exposure, while it was 6.36- and 4.79-fold, respectively, after recovery.

Table 2. TCS-induced variation in micronucleated cells (MN) and nucleo-cellular abnormalities (NCAs) during the exposure and recovery period.

\begin{tabular}{cccc}
\hline Treatment & & MN (\%) & NCA (\%) \\
\hline \multirow{2}{*}{ Control } & $\mathrm{E}$ & $0.33 \pm 0.11^{\mathrm{a}}$ & $1.27 \pm 0.30^{\mathrm{a}}$ \\
& $\mathrm{R}$ & $0.47 \pm 0.11^{\mathrm{p}}$ & $1.60 \pm 0.20^{\mathrm{p}}$ \\
\hline \multirow{2}{*}{ Acetone } & $\mathrm{E}$ & $0.33 \pm 0.11^{\mathrm{a}}$ & $1.20 \pm 0.20^{\mathrm{a}}$ \\
& $\mathrm{R}$ & $0.40 \pm 0.20^{\mathrm{p}}$ & $1.47 \pm 0.30^{\mathrm{p}}$ \\
\hline \multirow{2}{*}{$6.3 \mu \mathrm{g} / \mathrm{L}$} & $\mathrm{E}$ & $0.80 \pm 0.20^{\mathrm{ab}}$ & $1.80 \pm 0.20^{\mathrm{ab}}$ \\
& $\mathrm{R}$ & $1.27 \pm 0.30^{\mathrm{q}}$ & $3.53 \pm 0.30^{\mathrm{q}}$ \\
\hline \multirow{2}{*}{$12.6 \mu \mathrm{g} / \mathrm{L}$} & $\mathrm{E}$ & $1.13 \pm 0.30^{\mathrm{bc}}$ & $2.67 \pm 0.30^{\mathrm{b}}$ \\
& $\mathrm{R}$ & $1.93 \pm 0.30^{\mathrm{qr}}$ & $5.87 \pm 0.50^{\mathrm{r}}$ \\
\hline \multirow{2}{*}{$25.2 \mu \mathrm{g} / \mathrm{L}$} & $\mathrm{E}$ & $1.53 \pm 0.30^{\mathrm{cd}}$ & $4.13 \pm 0.50^{\mathrm{c}}$ \\
& $\mathrm{R}$ & $2.30 \pm 0.30^{\mathrm{r}}$ & $6.73 \pm 0.42^{\mathrm{r}}$ \\
\hline \multirow{2}{*}{$60 \mu \mathrm{g} / \mathrm{L}$} & $\mathrm{E}$ & $2.13 \pm 0.30^{\mathrm{d}}$ & $5.67 \pm 0.50^{\mathrm{d}}$ \\
& $\mathrm{R}$ & $3.46 \pm 0.41^{\mathrm{s}}$ & $9.27 \pm 0.42^{\mathrm{s}}$ \\
\hline Exposure & $\mathrm{F}$ & $26.00^{* *}$ & $74.13^{* *}$ \\
\hline Recovery & $\mathrm{F}$ & $49.43^{* *}$ & $208^{* *}$ \\
\hline
\end{tabular}

Values are mean $\pm S D, n=3$, and different alphabets represent significant $(p \leq 0.01)$ differences within the treatments after exposure $(\mathrm{E})(\mathrm{a}-\mathrm{d})$ and recovery $(\mathrm{R})(\mathrm{p}-\mathrm{s}) .{ }^{* *}$ represents $1 \%$ significance level.

\subsection{Comet Assay}

TCS-induced significant $(p \leq 0.01)$ concentration-dependent DNA damage in the form of increased TL, TM, OTM and TDNA (Table 3, Figure 3). At the highest concentration of TCS, the increase over control after 14 days was 0.78 -fold for TL, 1.98-fold for TM, 1.22-fold for OTM and 0.81-fold for TDNA, while after recovery, it was 0.41-, 0.90-, 0.50- and 0.47-fold for TL, TM, OTM and TDNA, respectively. Compared with the 14-days values, a significant $(p \leq 0.05)$ decrease was observed in all the parameters after recovery. The decline for TL, TM and OTM was significant $(p \leq 0.05)$ at all concentrations, but for TDNA, it was significant $(p \leq 0.05)$ at 25.2 and $60 \mu \mathrm{g} / \mathrm{L}$ only.

Table 3. TCS-induced variation in tail length (TL), tail moment (TM), olive tail moment (OTM) and percent tail DNA (TDNA) after the exposure and recovery period.

\begin{tabular}{cccccc}
\hline Treatment & & TL $(\boldsymbol{\mu m})$ & TM & OTM & TDNA (\%) \\
\hline \multirow{2}{*}{ Control } & $\mathrm{E}$ & $22.36 \pm 0.58^{\mathrm{a}}$ & $1.82 \pm 0.08^{\mathrm{a}}$ & $3.53 \pm 0.22^{\mathrm{a}}$ & $7.26 \pm 0.17^{\mathrm{a}}$ \\
& $\mathrm{R}$ & $21.71 \pm 0.61^{\mathrm{p}}$ & $1.90 \pm 0.12^{\mathrm{p}}$ & $3.39 \pm 0.04^{\mathrm{p}}$ & $7.68 \pm 0.20^{\mathrm{p}}$ \\
\hline \multirow{2}{*}{ Acetone } & $\mathrm{E}$ & $23.16 \pm 0.67^{\mathrm{a}}$ & $1.90 \pm 0.07^{\mathrm{a}}$ & $3.76 \pm 0.13^{\mathrm{a}}$ & $7.39 \pm 0.03^{\mathrm{a}}$ \\
& $\mathrm{R}$ & $21.68 \pm 0.42^{\mathrm{p}}$ & $1.85 \pm 0.12^{\mathrm{p}}$ & $3.43 \pm 0.31^{\mathrm{p}}$ & $7.56 \pm 0.25^{\mathrm{p}}$ \\
\hline \multirow{2}{*}{$6.3 \mu \mathrm{g} / \mathrm{L}$} & $\mathrm{E}$ & $29.17 \pm 0.34^{\mathrm{b}}$ & $2.64 \pm 0.13^{\mathrm{b}}$ & $4.48 \pm 0.09^{\mathrm{b}}$ & $8.37 \pm 0.10^{\mathrm{b}}$ \\
& $\mathrm{R}$ & $23.20 \pm 0.56^{\mathrm{pq}}$ & $1.91 \pm 0.04^{\mathrm{p}}$ & $3.44 \pm 0.16^{\mathrm{p}}$ & $7.77 \pm 0.35^{\mathrm{p}}$ \\
\hline \multirow{2}{*}{$12.6 \mu \mathrm{g} / \mathrm{L}$} & $\mathrm{E}$ & $30.70 \pm 1.14^{\mathrm{b}}$ & $3.20 \pm 0.11^{\mathrm{c}}$ & $4.98 \pm 0.14^{\mathrm{c}}$ & $9.50 \pm 0.31^{\mathrm{c}}$ \\
& $\mathrm{R}$ & $24.87 \pm 1.11^{\mathrm{qr}}$ & $2.37 \pm 0.15^{\mathrm{pq}}$ & $3.79 \pm 0.31^{\mathrm{p}}$ & $8.64 \pm 0.42^{\mathrm{p}}$ \\
\hline
\end{tabular}


Table 3. Cont.

\begin{tabular}{cccccc}
\hline Treatment & & TL $(\mu \mathrm{m})$ & TM & OTM & TDNA (\%) \\
\hline \multirow{2}{*}{$25.2 \mu \mathrm{g} / \mathrm{L}$} & $\mathrm{E}$ & $35.36 \pm 0.60^{\mathrm{c}}$ & $4.18 \pm 0.25^{\mathrm{d}}$ & $6.22 \pm 0.25^{\mathrm{d}}$ & $11.14 \pm 0.24^{\mathrm{d}}$ \\
& $\mathrm{R}$ & $26.82 \pm 0.95^{\mathrm{r}}$ & $2.60 \pm 0.19^{\mathrm{q}}$ & $4.05 \pm 0.15^{\mathrm{p}}$ & $8.77^{\mathrm{d}} \pm 0.25^{\mathrm{p}}$ \\
\hline \multirow{2}{*}{$60 \mu \mathrm{g} / \mathrm{L}$} & $\mathrm{E}$ & $39.56 \pm 1.71^{\mathrm{d}}$ & $5.42 \pm 0.17^{\mathrm{e}}$ & $7.84 \pm 0.16^{\mathrm{e}}$ & $13.18 \pm 0.58^{\mathrm{e}}$ \\
& $\mathrm{R}$ & $30.73 \pm 0.92^{\mathrm{s}}$ & $3.61 \pm 0.44^{\mathrm{r}}$ & $5.08 \pm 0.65^{\mathrm{q}}$ & $11.29^{\mathrm{a}} \pm 0.95^{\mathrm{q}}$ \\
\hline Exposure & $\mathrm{F}$ & $148.99^{* *}$ & $267.43^{* *}$ & $268.9^{* *}$ & $184.08^{* *}$ \\
\hline Recovery & $\mathrm{F}$ & $57.30^{* *}$ & $30.34^{* *}$ & $11.21^{* *}$ & $25.70^{* *}$ \\
\hline
\end{tabular}

Values are mean $\pm S D, n=3$, and different alphabets represent significant $(p \leq 0.01)$ differences within the treatments after exposure $(\mathrm{E})(\mathrm{a}-\mathrm{e})$ and recovery $(\mathrm{R})(\mathrm{p}-\mathrm{s}) .{ }^{* *}$ represents $1 \%$ significance level.

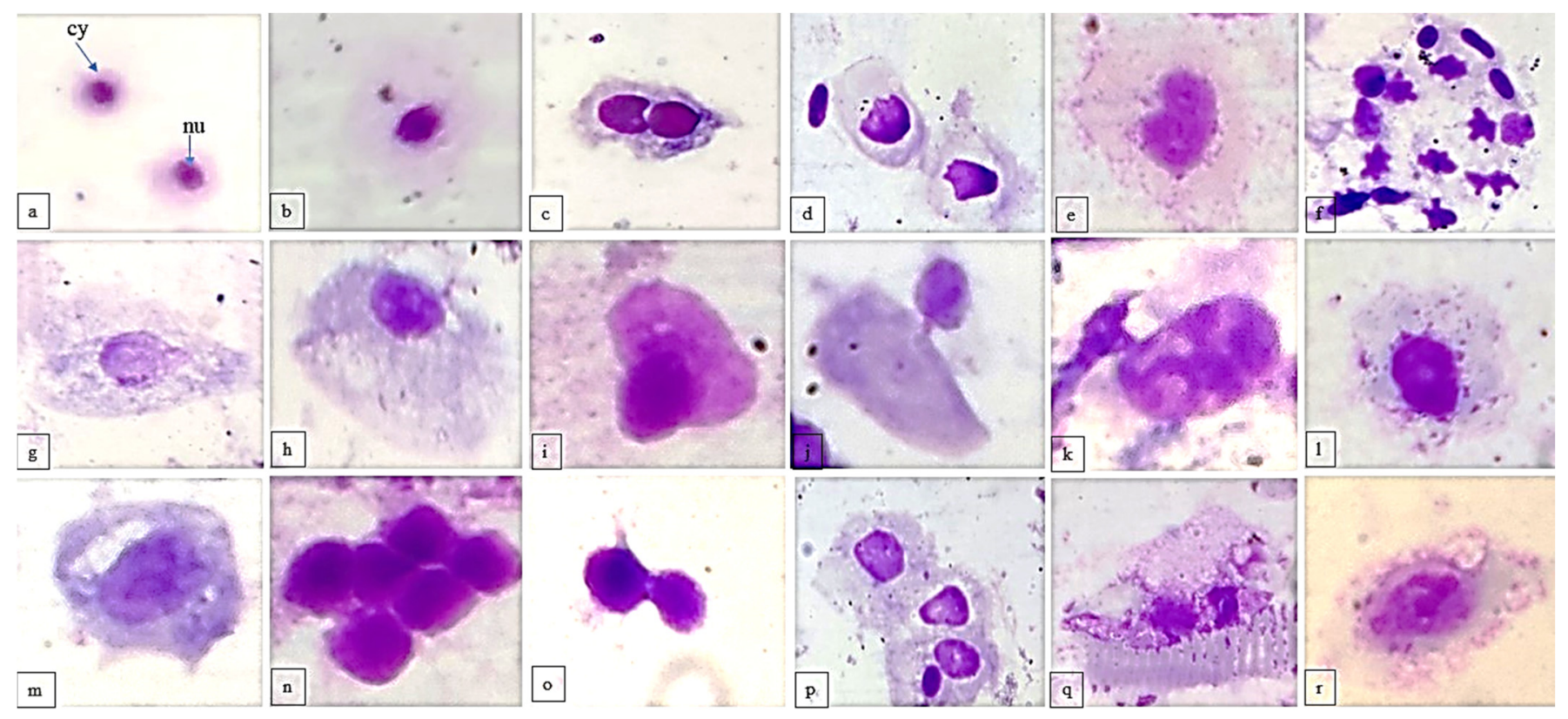

Figure 2. TCS-induced nuclear and cellular abnormalities during the exposure and recovery period: normal cell (a), micronucleus (b), binucleated or dacrocyte (c), blebbed nucleus (d), nuclear notch (e), deformed nucleus (f), nuclear bud $(\mathbf{g})$, extrusion nucleus $(\mathbf{h}, \mathbf{i})$, ghost cell and nucleoid $(\mathbf{j})$, nuclear fragmentation $(\mathbf{k})$, vesicle formation $(\mathbf{l})$, vacuolation $(\mathbf{m})$, stickiness (n), cytoplasmic bridge $(\mathbf{o})$, chain of cells $(\mathbf{p})$ and lytic or necrotic cells $(\mathbf{q}, \mathbf{r})$. cy = cytoplasm and nu-nucleus.
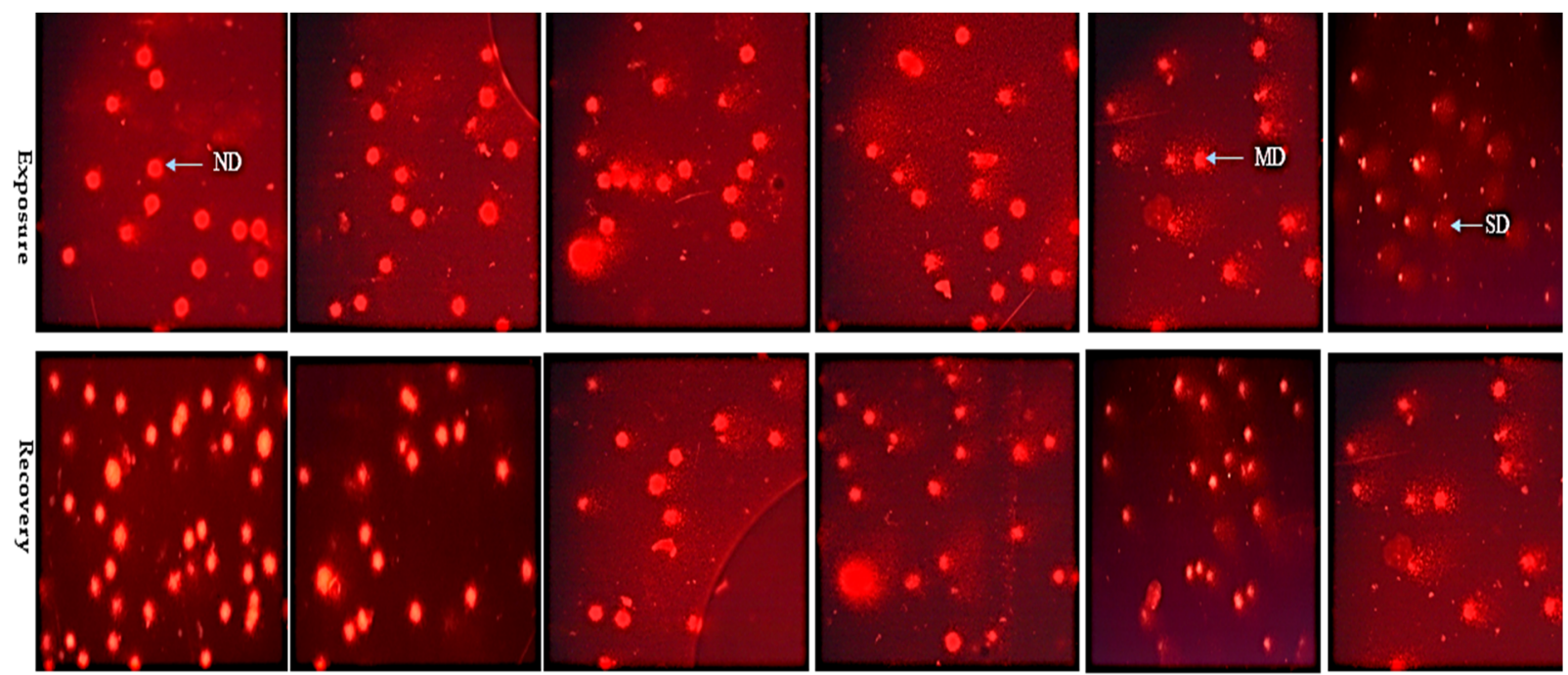

Control

Acetone

$6.3 \mu \mathrm{g} / \mathrm{L}$

$12.6 \mu \mathrm{g} / \mathrm{L}$

$25.2 \mu \mathrm{g} / \mathrm{L}$

$60 \mu \mathrm{g} / \mathrm{L}$

Figure 3. TCS-induced DNA damage during the exposure and recovery period. ND = no damage; MD = mild damage; $\mathrm{SD}=$ severe damage . 


\subsection{Biochemical Changes}

Values of all the parameters for solvent control were non-significantly different from control. TCS caused concentration-dependent alterations in the biochemical parameters after exposure, and the stress prolonged till the end of recovery period (Figures 4 and 5). Decline was observed in Glu, Chol, TP, UA and U (except for an increase at $60 \mu \mathrm{g} / \mathrm{L}$ after exposure) after exposure as well as the recovery period. On the other hand, decline in TG, Alb, Tbili and ALP after exposure was followed by an increase after recovery, while AST and ALT increased after exposure and recovery.
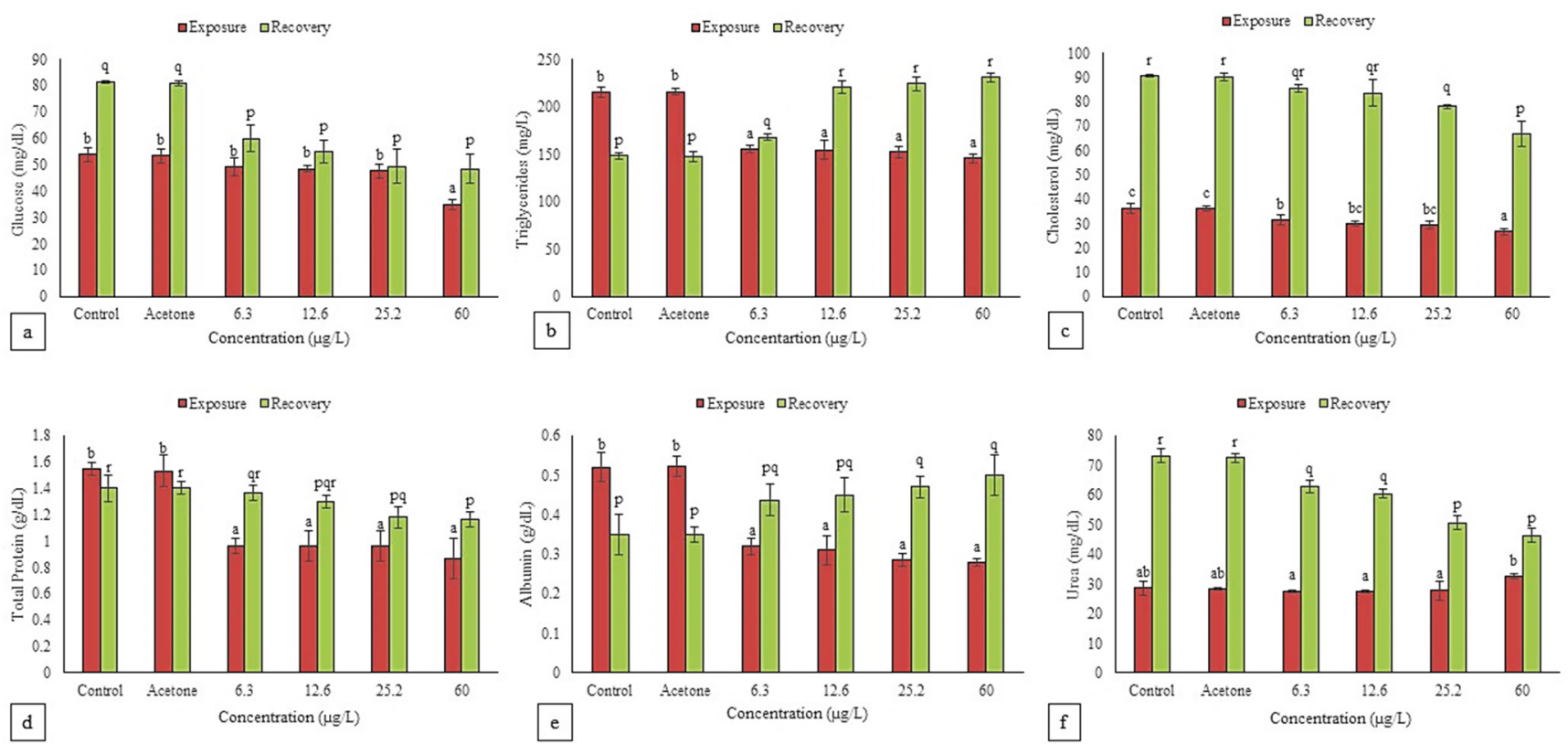

Figure 4. TCS-indued variation in the contents of glucose (a), triglycerides (b), cholesterol (c), total protein (d), albumin (e) and urea (f) in the hatchlings of L. rohita after the exposure and recovery period. Values are mean $\pm \mathrm{SD}, \mathrm{n}=3$, and different alphabets represent significant $(p \leq 0.05)$ differences within the treatments after exposure $(a-c)$ and recovery $(p-r)$.

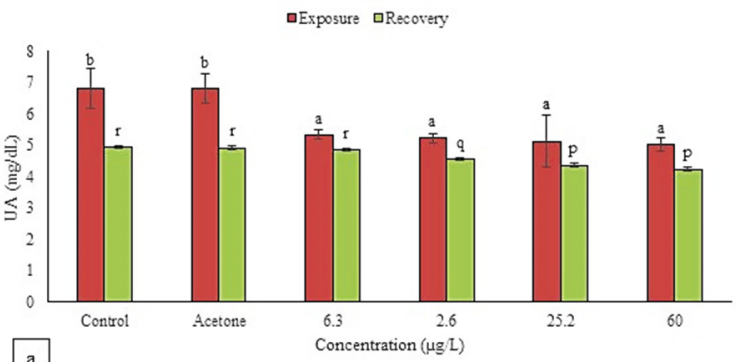

$\mathrm{a}$

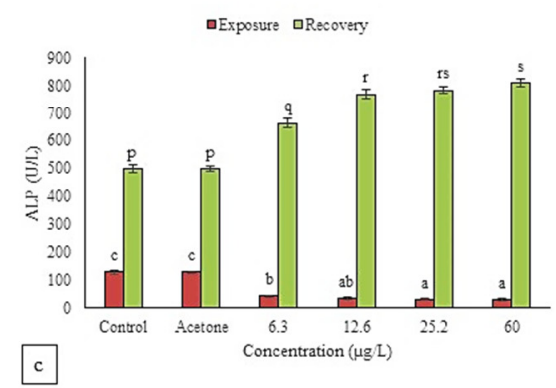

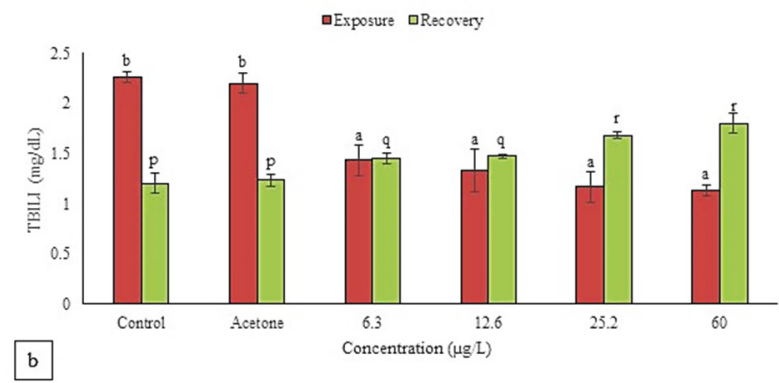

DExposure aRecovery
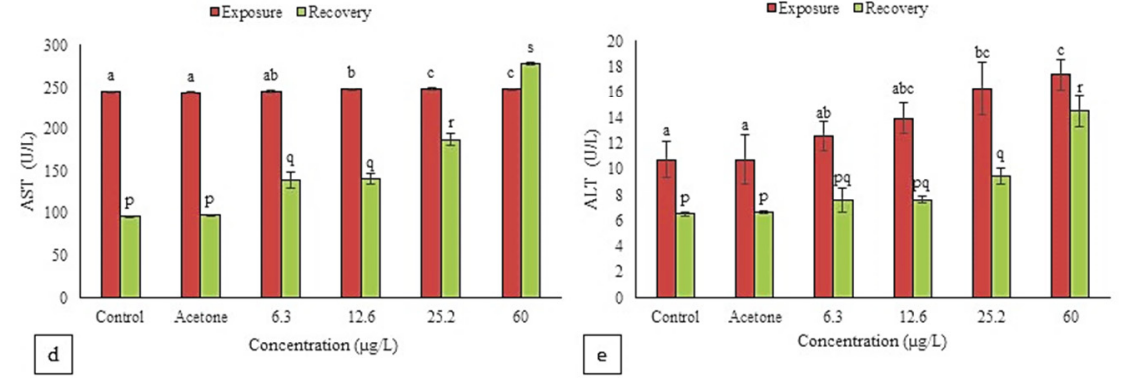

Figure 5. TCS-induced variations in the contents of uric acid (a) and total bilirubin (b) and activity of ALP (c), AST (d) and ALT (e) in the hatchlings of L. rohita after the exposure and recovery period. Values are mean $\pm S D, n=3$, and different alphabets represent significant $(p \leq 0.05)$ differences within the treatments after exposure $(\mathrm{a}-\mathrm{c})$ and recovery $(\mathrm{p}-\mathrm{s})$. 


\subsubsection{Glucose}

Decline over control in Glu was significant $(p \leq 0.01)$ only at $60 \mu \mathrm{g} / \mathrm{L}$ after exposure but at all the concentrations after 10 days of recovery. Although there was an increase over the exposure values in the level of Glu after recovery, but it was much less than that of control. At the highest concentration of TCS, decline over control was 35\% after exposure and $41 \%$ after recovery.

\subsubsection{Cholesterol and Triglycerides}

Chol declined significantly $(p \leq 0.01)$ over control after exposure and recovery, while decline in TG $(p \leq 0.01)$ after exposure was followed by an increase $(p \leq 0.01)$ after recovery. In the recovered hatchlings, levels of both TG (except for a significant decline at control and solvent control) and Chol increased significantly $(p \leq 0.05)$ compared with the $14 \mathrm{~d}$ values. Decline in Chol over control after recovery was lower compared with the exposure values at $6.3,12.6$ and $25.2 \mu \mathrm{g} / \mathrm{L}$ but the same at $60 \mu \mathrm{g} / \mathrm{L}(26 \%)$. Decline in TG after exposure (32\%) was followed by an increase (55\%) over control after recovery at the highest concentration.

\subsubsection{Total Protein and Albumin}

TP showed a significant $(p \leq 0.01)$ decline over control after exposure and recovery, while decline $(p \leq 0.01)$ in Alb after exposure was followed by an increase $(p \leq 0.01)$ after recovery. The recovery values of both $\mathrm{TP}$ and $\mathrm{Alb}$ were more than their respective exposure values. At the highest concentration, TP declined over control by $44 \%$ and $16 \%$ after exposure and recovery, respectively, while Alb declined over control by $46 \%$ after exposure but increased by $43 \%$ over control after recovery.

\subsubsection{Urea, Uric Acid and Total Bilirubin}

$\mathrm{U}$ (except for a significant increase at $60 \mu \mathrm{g} / \mathrm{L})$ and UA declined significantly $(p \leq 0.01)$ over control after exposure and recovery, while decline $(p \leq 0.01)$ in Tbili after exposure was followed by an increase over control $(p \leq 0.01)$ after recovery. Recovery values of $\mathrm{U}$ and Tbili (except for a decline in control and solvent control) were greater than the exposure values. However, UA after recovery was significantly $(p \leq 0.05)$ lower than the exposure level at all the concentrations.

\subsubsection{ALP, AST and ALT}

A significant decline $(p \leq 0.01)$ over control in ALP after exposure was followed by a significant increase $(p \leq 0.01)$ after recovery. At $60 \mu \mathrm{g} / \mathrm{L}$, it declined by $77 \%$ after exposure but increased by $62 \%$ after recovery. AST and ALT were significantly $(p \leq 0.01)$ induced by TCS during exposure as well as recovery period. At the highest concentration, increase over control in the activity of AST and ALT after recovery was much higher (190 and $124 \%$, respectively) than the exposure (1.5 and $62 \%$, respectively). However, in comparison with the exposure levels, AST (except for a significant rise at $60 \mu \mathrm{g} / \mathrm{L}$ ) and ALT showed decline (significant only at control 12.6 and $25.2 \mu \mathrm{g} / \mathrm{L}$ ), while the activity of ALP increased significantly $(p \leq 0.01)$ at all concentrations after recovery.

\section{Discussion}

PPCPs are found in majority of water bodies [34], so understanding the adverse effects of the environmentally relevant concentrations of these toxicants on aquatic organisms seems to be an integral component of environmental monitoring and management. Monitoring their effects on food fishes is very pertinent, as contaminated fish pose a direct threat to consumers, especially humans. The cyto-genotoxic effects of the selected concentrations of TCS were clearly visible from a concentration-dependent increase in the frequency of necrotic and apoptotic cells and the elevation of MN, NCA and comet parameters. Cytogenotoxicity of TCS seems mainly due to the formation of crosslinks by the chemical with DNA and the intercalating nature of its metabolites like 2, 8-dichlorodibenzo-P-dioxin [35]. Martin et al. [36] suggested that the main reason behind apoptosis caused by a xenobiotic is 
the activation of endogenous nucleases and the formation of oligonucleosomal fragments of DNA. The fragmentation of DNA is directly associated with an increase in the frequency of apoptotic cells [37], as is clear from the concentration-dependent increase in nuclear fragmentation and cell lysis during the depuration period.

TCS-induced stress is reported to elevate expression of caspase 3 and Bax in the neural stem cells of rats [38] and that of caspases (8, 9 and 3) and fas receptors in the neocortical neurons of Swiss mice [39]. Caspase 8 initiates exogenous pathway, while caspase 9 initiates endogenous pathway of apoptosis in stressed cells. TCS causes concentrationdependent membrane disruption, cell lysis and inhibition of protein synthesis, as suggested by Schweizer [14]. This directly supports our observations, and it could be the possible cause of cytotoxic effect of TCS. When defense system of a cell is unable to repair severe DNA damage, the damaged cell undergoes necroptosis or necrosis. In the present study, decreased cell viability and increased necrotic and apoptotic cell frequency in the hatchlings were supported by the results of Parenti et al. [17], who observed that $1 \mu \mathrm{g} / \mathrm{L} \mathrm{TCS}$ for $120 \mathrm{~h}$ significantly decreased cell viability and increased necrotic cell frequency in the embryos of Danio rerio. Our study is also corroborated by Binelli et al. [15], who observed that exposure of 1, 2 and $3 \mathrm{nM}$ TCS for $96 \mathrm{~h}$ caused a dose-dependent increase in apoptotic cell frequency in the hemocytes of zebra mussel. Decreased cell viability and increased apoptotic cell frequency were also reported in hepatocyte cell lines of zebra fish after $24 \mathrm{~h}$ of exposure to 0.5, 1 and $2 \mathrm{mg} / \mathrm{L} \mathrm{TCS} \mathrm{[40].}$

The clastogenic pollutants increase the mutation frequency in DNA, which leads to different types of nuclear and cellular abnormalities which can be easily observed with the help of MN assay. Micronuclei are the chromosomal fragments or the lagging chromosomes formed due to improper segregation of chromosomes during cell division or due to mitotic failure $[41,42]$. It has been highlighted that TCS disturbs genetic balance by blocking cytokinesis of normal cells, which may lead to carcinogenesis [43]. We also observed a concentration-dependent increase in binucleated cells during the post exposure period. TCS induces formation of reactive oxygen species that cause deleterious effects on nucleic acids and macromolecules [44], and this could be the probable reason for the greater increase in the MN and NCA frequencies during the post exposure period in the present study. Our results are consistent with the results of Binelli et al. [15], Emery [45], Vijitha et al. [16] and Paul et al. [18,19]. An increase in nuclear abnormalities has also been reported in blood cells of gold fish after exposure to $0.1399,0.2798$ and $0.5596 \mathrm{mg} / \mathrm{L}$ TCS for 14 days [46] and in Clarias gariepinus after 14 and 28 days of exposure to 0.30 and $1.60 \mathrm{mg} / \mathrm{L}$ TCS [47].

Comet assay is a simple, rapid and sensitive tool to evaluate the extent of DNA damage. Concentration-dependent increase in DNA damage in the present study was directly proportional to the increased frequency of apoptotic and necrotic cells during exposure as well as in the recovery period. TCS promotes the production of reactive oxygen species which break the crosslinks between DNA histones and DNA strands and cause DNA damage [19]. It has also been observed to alter DNA methylation and transcription of histone methyltransferases in the early life stages of zebra fish [48], which could be the possible reasons behind the dose-dependent increase in DNA damage in our study. The genotoxic potential of TCS has been reported in Driessena polymorpha [15], Tetrahymena thermophila [49], Eisenia fetida [50,51], Carassius auratus [46], Danio rerio [17], Pangasianodon hypophthalmus [18,19] and L. rohita [13]. Our results are supported by Hemalatha et al. [9] and Gyimah et al. [20], who reported significant DNA damage in L. rohita after exposure to 0.039 and $0.078 \mathrm{mg} / \mathrm{L} \mathrm{TCS}$ for 7, 14, 21, 28 and 35 days and in the liver of zebrafish after exposure of 50, 100 and $150 \mu \mathrm{g} / \mathrm{L}$ TCS for 30 days, respectively.

Glucose monitoring is highly preferred in ecotoxicological studies because it indicates the physiological health of an organism. The significant decline in glucose content after exposure and recovery period might be attributed to an enhanced rate of glycolysis in the hatchlings under the stress of TCS. Rapid utilization of glucose to compensate for high energy demand during oxidative stress might be the possible reason behind the decrease in 
glucose level [52]. Similarly, Hemalatha et al. [9] observed a significant decline in glucose levels of L. rohita after 35 days of exposure to 39 and $78 \mu \mathrm{g} / \mathrm{L}$ TCS. Hypoglycemia has also been reported in C. punctatus under the stress of monocrotophos [21] and malathion [53]. Chol and TG are essential components of the cell membrane and important energy sources. These are also involved in cell signaling and molecular recognition pathways [54]. The probable cause of reduced Chol and TG levels in the present study seems to be malnutrition, low absorption and improper biosynthesis, as suggested by Hatami et al. [55]. Not only during exposure, but even during the recovery period, the TCS-exposed hatchlings ate much less, and their weight was also lower compared with the control hatchlings. TCS impairs lipid metabolism [56], which could be the possible reason for decrease in TG and Chol levels in exposed hatchings. Agrahari et al. [21] suggested that the accumulation of pesticides in fish tissues may inhibit the synthesis of Chol. The decline in TG content could also be corelated with its mobilization to meet the constant energy demand and utilization in membrane biogenesis under stress $[54,57]$. The increased concentration of TG after recovery may be attributed to nephritic syndrome and metabolic disorders [58,59]. Similar results were reported in C. punctatus after 21 days of exposure to 200 and $400 \mu \mathrm{g} / \mathrm{L}$ paraquat [60] and 25 and $50 \mu \mathrm{g} / \mathrm{L}$ chlorpyrifos [55].

Proteins are the important biomolecules that play a critical role in almost all the structures and functions of living organisms [61]. The depleted protein content in the present study may be due to proteolysis as a result of elevated energy demand for maintaining homeostasis, tissue repair and detoxification reactions during stress. Previous reports also showed that TCS significantly decreased the protein content in C. punctatus [27], Oreochromis niloticus [16] and Oreochromis mossambicus [62]. Alb is the most dominant plasma protein having storage and transport functions [63]. A decline in Alb after exposure may be attributed to cellular destruction, liver necrosis and the impairment of protein synthesis machinery [18]. Our finding is corroborated by Bera et al. [64], who reported a decrease in serum Alb in P. hypophthalmus on exposure to TCS. However, an increase in Alb is suggested due to liver damage [65], and this could be the underlying cause for the observed increase in Alb after the recovery period.

AST and ALT are important transaminases that act as crucial links between protein and carbohydrate metabolism and the mobilization of amino acids for gluconeogenesis [9]. Increased activity of AST and ALT after exposure and recovery period suggests enhanced transamination for the channeling of amino acids in the citric acid cycle [55]. The liver is the main site for detoxification and removal of xenobiotics, so a high concentration of transaminases is found in hepatocytes. Hepatic injuries and disruption of the cell membrane by xenobiotics elevate the activity of AST and ALT $[55,66,67]$. Enhanced activity of transaminases after TCS exposure has also been reported in L. rohita and Catla catla $[9,28]$ and in embryos of L. rohita, Cyprinus carpio, Ctenopharyngodon idella and Cirrhinus mrigala [11,68]. ALP is an important enzyme present in the liver and cellular membranes and plays a key role in detoxification and membrane transport. The cells that line the bile duct of liver produce this enzyme [69]. The declined activity of ALP after exposure could be due to disruption of the plasma membrane, the inability of ion exchange channels to function and liver necrosis [55]. Exposure to TCS for 14 days and chlorpyrifos for 21 days was observed to significantly decrease the activity of ALP in catfish Pseudoplatystoma magdaleniatum [70] and C. carpio [55], respectively. However, increased ALP activity after recovery indicates damage to bile ducts [71]. During oxidative stress, rapid mobilization of metabolites and necrosis of cells can be linked with enhanced ALP activity [72], which directly supports our observations of a consecutive concentration-dependent increase in ALP activity and necrotic cells during exposure and recovery period.

$\mathrm{U}$ and UA are the final catabolic products of protein and purines, respectively, and their contents indicate the renal functioning of the organism [73]. Pesticidal exposure is suggested to cause various histopathological changes in the kidneys of fish (e.g., glomerular lesions, reduced nephron numbers, necrosis of hematopoietic tissue and degeneration of renal tubules) [74]. These could be the reasons for the declined contents of U and UA in the 
hatchlings in the present study. Hemalatha et al. [9] reported that TCS induced shrinkage of glomeruli and necrosis of renal tubules in L. rohita. The decline in U and UA in the present study could also be attributed to the inability of the liver to metabolize proteins and synthesize purines, respectively, as suggested by Adamu and Kori-Siakpere [75]. It seems that defects in renal reabsorption could have caused an increase in $U$ at the highest concentration of TCS. The depletion of Tbili after exposure also indicates hepatic dysfunction, because bilirubin is a predominant hepatic pigment formed from the breakdown of heme and porphyrin rings [76]. A decline in Tbili content has also been reported in fresh water fish C. punctatus after exposure to malathion [53]. The significant elevation in Tbili after recovery could be due to obstructions in bile ducts and liver damage, as suggested by Jyoti and Narayan [77].

\section{Conclusions}

It is concluded that sublethal concentrations of TCS induced cyto-genotoxicity and biochemical alterations in the hatchlings of L. rohita. TCS showed long-lasting effects, as the toxicity persisted till the end of the recovery period. The data clearly show that TCS disrupts the cellnuclear membranes and normal functioning of cell. It altered the levels of biochemical constituents by inducing hepatic and renal toxicity. Collectively, these changes may become the underlying cause for altering fish diversity of the natural ecosystems in the long run.

Author Contributions: A.K. and S.S. (Sunil Sharma) designed the experiment. S.S. (Sunil Sharma), O.I.D., M.A. and S.S. (Simran Sharma) performed the experiments and analyzed the data. A.K., S.S. (Sunil Sharma) and C.F. drafted the manuscript. All authors have read and approved the final manuscript.

Funding: This research was funded by the Council of Scientific and Industrial Research (CSIR, Grant no. 09/254 (0272)- 2017-EMR-1) and the University Grant Commission's Special Assistance Programme (UGC-SAP, Grant no. 4-4/2016/DRS-1).

Institutional Review Board Statement: Not applicable.

Informed Consent Statement: Not applicable.

Data Availability Statement: The data analyzed or generated during this study have been presented in the manuscript.

Acknowledgments: The authors are thankful to the Head, Department of Zoology Guru Nanak Dev University Amritsar for providing research facilities and the government fish seed farm Rajasansi, Amritsar for providing embryos of the experimental fish.

Conflicts of Interest: The authors declare no conflict of interest.

\section{References}

1. Dann, A.B.; Hontela, A. Triclosan: Environmental exposure, toxicity and mechanisms of action. J. Appl. Toxicol. 2011, 31, 285-311. [CrossRef]

2. Kasprzyk-Hordern, B.; Dinsdale, R.M.; Guwy, A.J. The removal of pharmaceuticals, personal care products, endocrine disruptors and illicit drugs during wastewater treatment and its impact on the quality of receiving waters. Water Res. 2009, 43, 363-380. [CrossRef]

3. Dhillon, G.S.; Kaur, S.; Pulicharla, R.; Brar, S.K.; Cledón, M.; Verma, M.; Surampalli, R.Y. Triclosan: Current status, occurrence, environmental risks and bioaccumulation potential. Int. J. Environ. Res. Public Health 2015, 12, 5657-5684. [CrossRef]

4. Ramaswamy, B.R.; Shanmugam, G.; Velu, G.; Rengarajan, B.; Larsson, D.G.J. GC-MS analysis and ecotoxicological risk assessment of triclosan, carbamazepine and parabens in Indian rivers. J. Hazard. Mater. 2011, 186, 1586-1593. [CrossRef]

5. Nag, S.K.; Das Sarkar, S.; Manna, S.K. Triclosan-an antibacterial compound in water, sediment and fish of River Gomti, India. Int. J. Environ. Health Res. 2018, 28, 461-470. [CrossRef]

6. Das, S.; Subir, S.; Nag, K.; Kumari, K.; Saha, K.; Bandyopadhyay, S. Occurrence and Safety Evaluation of Antimicrobial Compounds Triclosan and Triclocarban in Water and Fishes of the Multitrophic Niche of River Torsa, India. Arch. Environ. Contam. Toxicol. 2020, 79, 488-499. [CrossRef]

7. Dar, O.I.; Sharma, S.; Singh, K.; Kaur, A. Teratogenicity and accumulation of triclosan in the early life stages of four food fish during the bioassay. Ecotoxicol. Environ. Saf. 2019, 176, 346-354. [CrossRef] 
8. Sahu, V.K.; Karmakar, S.; Kumar, S.; Shukla, S.P.; Kumar, K. Triclosan toxicity alters behavioral and hematological parameters and vital antioxidant and neurological enzymes in Pangasianodon hypophthalmus (Sauvage, 1878). Aquat. Toxicol. 2018, 202, 145-152. [CrossRef]

9. Hemalatha, D.; Nataraj, B.; Rangasamy, B.; Shobana, C.; Ramesh, M. DNA damage and physiological responses in an Indian major carp Labeo rohita exposed to an antimicrobial agent triclosan. Fish Physiol. Biochem. 2019, 45, 1463-1484. [CrossRef]

10. Rauty, S.A.; Angus, R.A. Triclosan has endocrine-disrupting effects in male western mosquitofish, gambusia affinis. Environ. Toxicol. Chem. 2010, 29, 1287-1291. [CrossRef]

11. Dar, O.I.; Sharma, S.; Singh, K.; Sharma, A.; Bhardwaj, R.; Kaur, A. Biomarkers for the toxicity of sublethal concentrations of triclosan to the early life stages of carps. Sci. Rep. 2020, 10, 17322. [CrossRef]

12. Capkin, E.; Ozcelep, T.; Kayis, S.; Altinok, I. Antimicrobial agents, triclosan, chloroxylenol, methylisothiazolinone and borax, used in cleaning had genotoxic and histopathologic effects on rainbow trout. Chemosphere 2017, 182, 720-729. [CrossRef]

13. Sharma, S.; Dar, O.I.; Singh, K.; Thakur, S.; Kesavan, A.K.; Kaur, A. Genomic Markers for the Biological Responses of Triclosan Stressed Hatchlings of Labeo Rohita. ESPR 2021. [CrossRef]

14. Schweizer, H.P. Triclosan: A widely used biocide and its link to antibiotics. FEMS Microbiol. Lett. 2001, 202, 1-7. [CrossRef]

15. Binelli, A.; Cogni, D.; Parolini, M.; Riva, C.; Provini, A. In vivo experiments for the evaluation of genotoxic and cytotoxic effects of Triclosan in Zebra mussel hemocytes. Aquat. Toxicol. 2009, 91, 238-244. [CrossRef]

16. Vijitha, C.K.; Asifa, K.P.; Chitra, K.C. Assessment of genotoxic and haematological consequence of triclosan in the Assessment of genotoxic and haematological consequence of triclosan in the fish, Oreochromis niloticus (Linnaeus, 1758). Int. J. Appl. Res. 2017, 3, 101-109.

17. Parenti, C.C.; Ghilardi, A.; Della Torre, C.; Mandelli, M.; Magni, S.; Del Giacco, L.; Binelli, A. Environmental concentrations of triclosan activate cellular defence mechanism and generate cytotoxicity on zebrafish (Danio rerio) embryos. Sci. Total Environ. 2019, 650, 1752-1758. [CrossRef]

18. Paul, T.; Shukla, S.P.; Kumar, K.; Poojary, N.; Kumar, S. Effect of temperature on triclosan toxicity in Pangasianodon hypophthalmus (Sauvage, 1878): Hematology, biochemistry and genotoxicity evaluation. Sci. Total Environ. 2019, 668, 104-114. [CrossRef]

19. Paul, T.; Kumar, S.; Shukla, S.P.; Pal, P.; Kumar, K.; Poojary, N.; Biswal, A.; Mishra, A. A multi-biomarker approach using integrated biomarker response to assess the effect of $\mathrm{pH}$ on triclosan toxicity in Pangasianodon hypophthalmus (Sauvage, 1878). Environ. Pollut. 2020, 260, 114001. [CrossRef]

20. Gyimah, E.; Dong, X.; Qiu, W.; Zhang, Z.; Xu, H. Sublethal concentrations of triclosan elicited oxidative stress, DNA damage, and histological alterations in the liver and brain of adult zebrafish. Environ. Sci. Pollut. Res. 2020, 27, 17329-17338. [CrossRef]

21. Agrahari, S.; Pandey, K.C.; Gopal, K. Biochemical alteration induced by monocrotophos in the blood plasma of fish, Channa punctatus (Bloch). Pestic. Biochem. Physiol. 2007, 88, 268-272. [CrossRef]

22. Prokić, M.D.; Gavrilović, B.R.; Radovanović, T.B.; Gavrić, J.P.; Petrović, T.G.; Despotović, S.G.; Faggio, C. Studying microplastics: Lessons from evaluated literature on animal model organisms and experimental approaches. J. Hazard. Mater. 2021, 414, 125476. [CrossRef]

23. Sinha, R.; Jindal, R.; Faggio, C. Protective effect of emblica officinalis in cyprinus carpio against hepatotoxicity induced by malachite green: Ultrastructural and molecular analysis. Appl. Sci. 2021, 11, 3507. [CrossRef]

24. Vajargah, M.F.; Mohsenpour, R.; Yalsuyi, A.M.; Galangash, M.M.; Faggio, C. Evaluation of Histopathological Effect of Roach (Rutilus rutilus caspicus) in Exposure to Sub-Lethal Concentrations of Abamectin. Water. Air. Soil Pollut. 2021, 232, 1-8. [CrossRef]

25. Canli, E.G.; Dogan, A.; Canli, M. Serum biomarker levels alter following nanoparticle $\left(\mathrm{Al}_{2} \mathrm{O}_{3}, \mathrm{CuO}\right.$, $\left.\mathrm{TiO} \mathrm{O}_{2}\right)$ exposures in freshwater fish (Oreochromis niloticus). Environ. Toxicol. Pharmacol. 2018, 62, 181-187. [CrossRef]

26. Sethuraman, S.; Kumar, T.R.; Vivekananthan, T. Triclosan Induced Alterations of Biochemical Parameters in Zebra Fish Brachydaniorerio (Ham.) and their Productive Role by Dietary Supplementation of Garlic Extract and L-Ascorbic acid (Vitamin C). Asian J. Pharmacol. Toxicol. 2015, 03, 5-12.

27. Kola, R.K.; Mohd, A.R.; Yalavarthy, P.D. Research Article Effect of Triclosan on Total Protein Content in Fresh Water Fish, Channa Punctatus. Int. J. Recent Sci. Res. 2015, 6, 4641-4643.

28. Hemalatha, D.; Rangasamy, B.; Nataraj, B.; Ramesh, M. Assessment of triclosan impact on enzymatic biomarkers in an Indian major carp, Catla catla. J. Basic Appl. Zool. 2019, 80, 1-8. [CrossRef]

29. Sharma, S.; Dar, O.I.; Singh, K.; Kaur, A.; Faggio, C. Triclosan elicited biochemical and transcriptomic alterations in Labeo rohita larvae. Environ. Toxicol. Pharmacol. 2021, 88, 103748. [CrossRef]

30. Cahova, J.; Blahova, J.; Plhalova, L.; Svobodova, Z.; Faggio, C. Do Single-Component and Mixtures Selected Organic UV Filters Induce Embryotoxic Effects in Zebrafish (Danio rerio)? Water 2021, 13, 2203. [CrossRef]

31. Er, A.; Uçkan, F.; Rivers, D.B.; Sak, O. Cytotoxic effects of parasitism and application of venom from the endoparasitoid Pimpla turionellae on hemocytes of the host Galleria mellonella. J. Appl. Entomol. 2011, 135, 225-236. [CrossRef]

32. Sharma, M.; Chadha, P. Widely used non-ionic surfactant 4-nonylphenol: Showing genotoxic effects in various tissues of Channa punctatus. Environ. Sci. Pollut. Res. 2017, 24, 11331-11339. [CrossRef]

33. Singh, N.P.; McCoy, M.T.; Tice, R.R.; Schneider, E.L. A simple technique for quantitation of low levels of DNA damage in individual cells. Exp. Cell Res. 1988, 175, 184-191. [CrossRef] 
34. Freitas, R.; Silvestro, S.; Coppola, F.; Meucci, V.; Battaglia, F.; Intorre, L.; Soares, A.M.V.M.; Pretti, C.; Faggio, C. Combined effects of salinity changes and salicylic acid exposure in Mytilus galloprovincialis. Sci. Total Environ. 2020, 715, 136804. [CrossRef]

35. Aranami, K.; Readman, J.W. Photolytic degradation of triclosan in freshwater and seawater. Chemosphere 2007, 66, 1052-1056. [CrossRef]

36. Martin, S.J.; Green, D.R.; Cotter, T.G. Dicing with death: Dissecting the components of the apoptosis machinery. Trends Biochem. Sci. 1994, 19, 26-30. [CrossRef]

37. Steinert, S.A. Contribution of apoptosis to observed DNA damage in mussel cells. Mar. Environ. Res. 1996, 42, 253-259. [CrossRef]

38. Park, B.K.; Gonzales, E.L.T.; Yang, S.M.; Bang, M.; Choi, C.S.; Shin, C.Y. Effects of triclosan on neural stem cell viability and survival. Biomol. Ther. 2016, 24, 99-107. [CrossRef]

39. Szychowski, K.A.; Sitarz, A.M.; Wojtowicz, A.K. Triclosan induces Fas receptor-dependent apoptosis in mouse neocortical neurons in vitro. Neuroscience 2015, 284, 192-201. [CrossRef]

40. Guidony, N.S.; Scaini, J.L.R.; Oliveira, M.W.B.; Machado, K.S.; Bastos, C.; Escarrone, A.L.; Souza, M.M. ABC proteins activity and cytotoxicity in zebrafish hepatocytes exposed to triclosan. Environ. Pollut. 2020, 116368. [CrossRef]

41. Pernot, E.; Hall, J.; Baatout, S.; Benotmane, M.A.; Blanchardon, E.; Bouffler, S.; El Saghire, H.; Gomolka, M.; Guertler, A.; Harms-Ringdahl, M.; et al. Ionizing radiation biomarkers for potential use in epidemiological studies. Mutat. Res.-Rev. Mutat. Res. 2012, 751, 258-286. [CrossRef]

42. Sabharwal, R.; Verma, P.; Syed, M.A.; Sharma, T.; Subudhi, S.K.; Mohanty, S.; Gupta, S. Emergence of micronuclei as a genomic biomarker. Indian J. Med. Paediatr. Oncol. 2015, 36, 212-218. [CrossRef]

43. Rodilla, V. Origin and evolution of binucleated cells and binucleated cells with micronuclei in cisplatin-treated CHO cultures. Mutat. Res. Toxicol. 1993, 300, 281-291. [CrossRef]

44. Nwani, C.D.; Lakra, W.S.; Nagpure, N.S.; Kumar, R.; Kushwaha, B.; Srivastava, S.K. Mutagenic and genotoxic effects of carbosulfan in freshwater fish Channa punctatus (Bloch) using micronucleus assay and alkaline single-cell gel electrophoresis. Food Chem. Toxicol. 2010, 48, 202-208. [CrossRef]

45. Emery, D. Assessing the Genotoxicity of Triclosan in Tadpoles of the American Bullfrog, Lithobates Catesbeianus. 2012, p. 10. Available online: https:/ / doi.org/10.25772/H46E-PZ53 (accessed on 31 August 2021).

46. Wang, F.; Xu, R.; Zheng, F.; Liu, H. Effects of triclosan on acute toxicity, genetic toxicity and oxidative stress in goldfish (Carassius auratus). Exp. Anim. 2018, 67, 219-227. [CrossRef]

47. Jimoh, R.O. Sublethal and environmentally relevant concentrations of triclosan and triclocarban induce histological, genotoxic, and embryotoxic effects in Clarias gariepinus (Burchell, 1822). Environ. Sci. Pollut. Res. 2021, 28, 31071-31083. [CrossRef]

48. Falisse, E.; Ducos, B.; Stockwell, P.A.; Morison, I.M.; Chatterjee, A.; Silvestre, F. DNA methylation and gene expression alterations in zebrafish early-life stages exposed to the antibacterial agent triclosan. Environ. Pollut. 2018, 243, 1867-1877. [CrossRef]

49. Gao, L.; Yuan, T.; Cheng, P.; Bai, Q.; Zhou, C.; Ao, J.; Wang, W.; Zhang, H. Effects of triclosan and triclocarban on the growth inhibition, cell viability, genotoxicity and multixenobiotic resistance responses of Tetrahymena thermophila. Chemosphere 2015, 139, 434-440. [CrossRef]

50. Lin, D.; Zhou, Q.; Xie, X.; Liu, Y. Potential biochemical and genetic toxicity of triclosan as an emerging pollutant on earthworms (Eisenia fetida). Chemosphere 2010, 81, 1328-1333. [CrossRef]

51. Lin, D.; Li, Y.; Zhou, Q.; Xu, Y.; Wang, D. Effect of triclosan on reproduction, DNA damage and heat shock protein gene expression of the earthworm Eisenia fetida. Ecotoxicology 2014, 23, 1826-1832. [CrossRef]

52. Jeon, J.; Lim, H.K.; Kannan, K.; Kim, S.D. Effect of perfluorooctanesulfonate on osmoregulation in marine fish, Sebastes schlegeli, under different salinities. Chemosphere 2010, 81, 228-234. [CrossRef]

53. Bharti, S.; Rasool, F. Analysis of the biochemical and histopathological impact of a mild dose of commercial malathion on Channa punctatus (Bloch) fish. Toxicol. Rep. 2021, 8, 443-455. [CrossRef]

54. Van Meer, G.; Voelker, D.R.; Feigenson, G.W. Membrane lipids: Where they are and how they behave. Nat. Rev. Mol. Cell Biol. 2008, 9, 112-124. [CrossRef]

55. Hatami, M.; Banaee, M.; Nematdoost Haghi, B. Sub-lethal toxicity of chlorpyrifos alone and in combination with polyethylene glycol to common carp (Cyprinus carpio). Chemosphere 2019, 219, 981-988. [CrossRef]

56. Chai, L.; Chen, A.; Luo, P.; Zhao, H.; Wang, H. Histopathological changes and lipid metabolism in the liver of Bufo gargarizans tadpoles exposed to Triclosan. Chemosphere 2017, 182, 255-266. [CrossRef]

57. Santos, C.R.; Schulze, A. Lipid metabolism in cancer. FEBS J. 2012, 279, 2610-2623. [CrossRef]

58. Yang, J.L.; Chen, H.C. Effects of gallium on common carp (Cyprinus carpio): Acute test, serum biochemistry, and erythrocyte morphology. Chemosphere 2003, 53, 877-882. [CrossRef]

59. Banaee, M.; Akhlaghi, M.; Soltanian, S.; Sureda, A.; Gholamhosseini, A.; Rakhshaninejad, M. Combined effects of exposure to sub-lethal concentration of the insecticide chlorpyrifos and the herbicide glyphosate on the biochemical changes in the freshwater crayfish Pontastacus leptodactylus. Ecotoxicology 2020, 29, 1500-1515. [CrossRef]

60. Banaee, M.; Nemadoost Haghi, B.; Tahery, S.; Shahafve, S.; Vaziriyan, M. Effects of Sub-Lethal Toxicity of Paraquat on Blood Biochemical Parameters of Common Carp, Cyprinus carpio (Linnaeus, 1758). Iran. J. Toxicol. 2016, 10, 1-5. [CrossRef]

61. Onck, P. Protein Mechanics: From Amino Acid to Swimming Cells. Procedia IUTAM 2017, 20, 73-80. [CrossRef]

62. Deepika, S.; Padmavathy, P.; Srinivasan, A.; Sugumar, G.; Jawahar, P. Effect of triclosan (TCS) on the protein content and associated histological changes on tilapia, Oreochromis mossambicus (Peters, 1852). Environ. Sci. Pollut. Res. 2021, 1-9. [CrossRef] 
63. Ao, J.; Gao, L.; Yuan, T.; Jiang, G. Interaction mechanisms between organic UV filters and bovine serum albumin as determined by comprehensive spectroscopy exploration and molecular docking. Chemosphere 2015, 119, 590-600. [CrossRef]

64. Krishna, K.; Kumar, S.; Paul, T.; Pani, K.; Shukla, S.P. Triclosan induces immunosuppression and reduces survivability of striped cat fi sh Pangasianodon hypophthalmus during the challenge to a fi sh pathogenic bacterium Edwardsiella tarda. Environ. Res. 2020, 186, 109575. [CrossRef]

65. Niemelä, O.; Alatalo, P. Biomarkers of alcohol consumption and related liver disease. Scand. J. Clin. Lab. Investig. 2010, 70, 305-312. [CrossRef]

66. Miri, M.; Rahdari, A. Sub lethal effects of copper oxide (CuO) nanoparticles on blood parameters of common carp (Cyprinus Carpio). J. Biodivers. Environ. Sci. 2015, 6, 283-291.

67. Hamed, H.S.; Abdel-Tawwab, M. Dietary pomegranate (Punica granatum) peel mitigated the adverse effects of silver nanoparticles on the performance, haemato-biochemical, antioxidant, and immune responses of Nile tilapia fingerlings. Aquaculture 2021, 540, 736742. [CrossRef]

68. Dar, O.I.; Sharma, S.; Singh, K.; Sharma, A.; Bhardwaj, R.; Kaur, A. Biochemical markers for prolongation of the acute stress of triclosan in the early life stages of four food fishes. Chemosphere 2020, 247, 125914. [CrossRef]

69. Giang, P.T.; Burkina, V.; Sakalli, S.; Schmidt-Posthaus, H.; Rasmussen, M.K.; Randak, T.; Grabic, R.; Grabicova, K.; Fedorova, G.; Koba, O.; et al. Effects of Multi-Component Mixtures from Sewage Treatment Plant Effluent on Common Carp (Cyprinus carpio) under Fully Realistic Condition. Environ. Manag. 2019, 63, 466-484. [CrossRef]

70. Gallego, R.S.E.; Peñuela, G.A.; Martínez-López, E. Enzymatic activity changes in striped catfish Pseudoplatystoma magdaleniatum, induced by exposure to different concentrations of ibuprofen and triclosan. Chemosphere 2021, 271, 129399. [CrossRef]

71. Elia, A.C.; Pacini, N.; Fioravanti, M.L.; Dörr, A.J.M.; Zaccaroni, A.; Parmeggiani, A.M.; Gustinelli, A.; Mordenti, O.; Abete, M.C.; Prearo, M. Assessment of detoxifying markers for florfenicol in Rainbow Trout Liver. J. Aquat. Anim. Health 2016, 28, 258-265. [CrossRef]

72. Lakra, K.C.; Banerjee, T.K.; Lal, B. Coal mine effluent-induced metal bioaccumulation, biochemical, oxidative stress, metallothionein, and histopathological alterations in vital tissues of the catfish, Clarias batrachus. Environ. Sci. Pollut. Res. 2021, 28, 25300-25315. [CrossRef]

73. Banaee, M.; Sureda, A.; Mirvaghefi, A.R.; Rafei, G.R. Effects of long-term silymarin oral supplementation on the blood biochemical profile of rainbow trout (Oncorhynchus mykiss). Fish Physiol. Biochem. 2011, 37, 885-896. [CrossRef]

74. Banaee, M. Physiological Dysfunction in Fish After Insecticides Exposure. Insectic.-Dev. Safer More Eff. Technol. 2013, 103-142. [CrossRef]

75. Adamu, K.M.; Kori-Siakpere, O. Effects of sublethal concentrations of tobacco (Nicotiana tobaccum) leaf dust on some biochemical parameters of Hybrid catfish (Clarias gariepinus and Heterobranchus bidorsalis). Braz. Arch. Biol. Technol. 2011, 54, 183-196. [CrossRef]

76. Jee, J.H.; Masroor, F.; Kang, J.C. Responses of cypermethrin-induced stress in haematological parameters of Korean rockfish, Sebastes schlegeli (Hilgendorf). Aquac. Res. 2005, 36, 898-905. [CrossRef]

77. Jyothi, B.; Narayan, G. Certain pesticide-induced carbohydrate metabolic disorders in the serum of freshwater fish Clarias batrachus (Linn.). Food Chem. Toxicol. 1999, 37, 417-421. [CrossRef] 